\title{
Leaching Characteristics of the Metal Waste Form From the Electrometallurgical Treatment Process: Product Consistency Testing
}

\author{
By:
}

\section{S.G. Johnson, D.D. Keiser, S.M. Frank, T. DiSanto, and M.Noy}

Nuclear Technology Division

Argonne National Laboratory

P. O. Box 2528

Idaho Falls, ID 83403-2528

\begin{abstract}
The submitted manuscript has been created by the University of Chicago as Operator of Argonne National Laboratory ("Argonne") under Contract No. W-31-109-ENG-38 with the U.S. Department of Energy. The U.S. Government retains for itself, and others acting on its behalf, a paid-up, nonexclusive, irrevocable worldwide license in said article to reproduce, prepare derivative works, distribute copies to the public, and perform publicly and display publicly, by or on behalf of the Government.
\end{abstract}

Materials Research Society

Scientific Basis for Waste Management XXIII

Boston, MA

November 29 - December 3, 1999

\footnotetext{
*Work supported by the U. S. Department of Energy, Office of Nuclear Energy, Science and Technology, and the Office of Environmental Management, under contract W-31-109-Eng-38.
} 


\section{DISCLAIMER}

This report was prepared as an account of work sponsored by an agency of the United States Government. Neither the United States Government nor any agency thereof, nor any of their employees, make any warranty, express or implied, or assumes any legal liability or responsibility for the accuracy, completeness, or usefuiness of any information, apparatus, product, or process disclosed, or represents that its use would not infringe privately owned rights. Reference herein to any specific commercial product, process, or service by trade name, trademark, manufacturer, or otherwise does not necessarily constitute or imply its endorsement, recommendation, or favoring by the United States Government or any agency thereof. The views and opinions of authors expressed herein do not necessarily state or reflect those of the United States Government or any agency thereof. 


\section{DISCLAIMER}

\section{Portions of this document may be illegible in electronic image products. Images are produced from the best available original document.}




\author{
S. G. Johnson, D. D. Keiser, S. M. Frank, T. DiSanto and M. Noy \\ Argonne National Laboratory-West \\ P.O. 2528 \\ Idaho Falls, ID 83403
}

\begin{abstract}
Argonne National Laboratory is developing an electrometallurgical treatment for spent fuel from the experimental breeder reactor II. A product of this treatment process is a metal waste form that incorporates the stainless steel cladding hulls, zirconium from the fuel and the fission products that are noble to the process, i.e., $\mathrm{Tc}, \mathrm{Ru}, \mathrm{Nb}, \mathrm{Pd}, \mathrm{Rh}, \mathrm{Ag}$. The nominal composition of this waste form is stainless steel/15 wt\% zirconium/ 1-4 wt\% noble metal fission products $/ 1-2 \mathrm{wt} \%$ U. Leaching results are presented from several tests and sample types: 1) 2 week monolithic immersion tests on actual metal waste forms produced from irradiated cladding hulls, 2 ) long term ( $>2$ years) pulsed flow tests on samples containing technetium and uranium and 3) crushed sample immersion tests on cold simulated metal waste form samples. The test results will be compared and their relevance for waste form product consistency testing discussed.
\end{abstract}

\title{
INTRODUCTION
}

The electrometallurgical (EM) treatment process of spent fuel at Argonne National Laboratory (ANL) yields three product streams: a uranium metal product, a contaminated salt waste stream and an irradiated cladding hull waste stream[1]. The stainless steel cladding hulls are consolidated into a metal waste ingot with a nominal composition of stainless steel components ( 80 wt\%), zirconium (15 wt\%), fission products noble to the process and residual actinides (5 wt\%). The last two categories include elements such as $\mathrm{Tc}, \mathrm{Ru}, \mathrm{Ag}, \mathrm{Rh}, \mathrm{Pd}, \mathrm{Nb}, \mathrm{U}$ and $\mathrm{Pu}[2]$. The topic of waste form process qualification has been addressed for borosilicate glass [3] and the plutonium immobilization product [4]. The ceramic waste form to be produced from the EM process at Argonne is sufficiently like the borosilicate glass waste form that it will likely follow a pathway very similar to that waste form. However, the metal waste form is unlike anything in the DOE high level waste complex. The tests to be applied to the finished product to demonstrate that the production process is well controlled are currently being considered and developed. This paper addresses some of that work.

Borosilicate glass high level waste relies on input process stream analysis, a short-term immersion test (ASTM C1285-97), and determination of crystalline content to establish the basis of a wellcontrolled process. The metal waste form resulting from the EM process can similarly rely on input stream analysis, although this information is not always timely and the issue of a statistical sample of a large collection of cladding hulls is unresolved. The analysis of the final product to complement this input stream information would provide for a better degree of process control. The methods discussed in this paper involve different variations of immersion tests that either have been applied to actual waste forms produced from irradiated cladding hulls (monolithic static immersion test), technetium or uranium doped alloy samples (pulsed flow immersion test) or cold alloy samples (crushed sample immersion test). The emphasis is on what these tests could tell one regarding the metal waste form produced and their applicability in a hot cell setting for process control.

\section{EXPERIMENTAL}

\section{Monolithic Static Immersion Test}

Static immersion tests were performed on samples from irradiated metal waste ingots CFMW 06 and 07 . These will be referred to hereafter as ingots $6 \& 7$ for simplicity. A total of four samples were obtained by core drilling the as-produced ingot in a hot cell facility. The cores were prepared further by squaring each end by using a saw to provide for a regular geometry (right circular cylinder). The physical dimensions of the cores were $8.0 \mathrm{~mm}$ in diameter with a variable length close to $10 \mathrm{~mm}$. The resulting monoliths were cleaned several times using absolute ethanol and an ultrasonic bath. The final dimensions and weights were then measured and the leachant solutions prepared. Two leachants were utilized, ASTM type I water and SJ-13 water[5]. The vessels used were of stainless steel construction (Parr Co.) and also consisted of a small titanium pedestal for sample placement. The surface-area-of-monolith to volume-of-leachant ratio used was $50 \mathrm{~m}^{-1}$. Blank 
solutions were run simultaneously with the samples in vessels. The vessels were sealed and placed into a constant temperature oven at $90^{\circ} \mathrm{C}$ for a period of two weeks ( $t / 6.8$ hours). The tests were terminated and the leachates obtained. The vessels were subjected to an 18 hour acid strip consisting of $1 \% \mathrm{HNO}_{3}$. The mass of the monoliths was measured following the 14 day test.

\section{Long-Term Pulsed Flow Test}

The doped metal alloy samples were cast in yttria crucibles under an argon atmosphere using a muffle furnace. The casting temperature was $1600^{\circ} \mathrm{C}$. For further details regarding sample preparation please see ref. [5]. The long term pulsed flow immersion test was developed to evaluate the performance of high-level waste forms under repository like conditions [6-8]. The particulars of this test can be found in ref. [5]. The sample is placed into a stainless steel (304) vessel. The leachant used is SJ-13 water, with a surface area to volume ratio of $50 \mathrm{~m}^{-1}$. The vessel is placed into a constant temperature oven at $90^{\circ} \mathrm{C}$. It is removed on a periodic basis, allowed to cool, weighed and then the solution is sampled using a pipette. The aliquot of leachate removed is typically 5-10\% of the total. The volume removed is replaced with fresh leachant and the vessel is returned to the oven.

\section{Crushed Sample Test}

The material used for this investigation was a $316 \mathrm{SS} / 15 \mathrm{wt} \% \mathrm{Zr}$ alloy ingot. Three methods of sample preparation were investigated and the resulting material was then subjected to an immersion test modeled after ASTM C1285-97 [9]. The sample fraction used for the test was sieved and the -100 mesh to +200 mesh fraction was used. The surface area-to-volume of leachant ratio was 2000 $\mathrm{m}^{-1}$, the test duration was 14 days and the temperature was $90^{\circ} \mathrm{C}$. The leach vessels used were Teflon. The three sample preparation methods are listed and described below:

1) A file was used to generate material, that was then introduced into the micromill for a short grind using a Stellite blade and chamber. The material was then sieved and washed for the test.

2) A bandsaw was used to generate material which was then introduced into the micromill for further processing before being sieved and used for the test.

3) A drill press equipped with a coring bit was used to obtain shavings that were than further processed using a micromill. The drill press was operated at a slow speed to minimize heating.

\section{Analysis Methods}

The elemental analyses for the solutions generated from the three immersion tests described above were performed using an Inductively Coupled Plasma Mass Spectrometer. However, technetium is determined using liquid scintillation and uranium from the pulsed flow test was analyzed via fluorimetry. Typical precision for either method is $\pm 10-20 \%$. The SEM work was performed with a Zeiss DSM $960 \AA$ A digital scanning electron microscope. The energy dispersive detector (EDS) was provided by Oxford Instruments.

\section{Presentation of Results}

The normalized mass loss (NML, $\mathrm{g} / \mathrm{m}^{2}$ ) for the above tests was calculated using eq. (1); where,

$$
N M L=\left\{A_{i} /\left[m_{i} \times S A\right]\right\}
$$

$A_{i}=$ the amount of component $i$ in the solution in grams

$m_{i}=$ the mass fraction of component $i$ in the sample being tested

$\mathrm{SA}=$ the geometrical surface area of the sample being tested

\section{RESULTS AND DISCUSSION}

Monolithic Static Immersion Test

The two-week static leach test of the eight samples from metal waste ingots $6 \& 7$ yielded several important results. The mass loss was less than $0.001 \mathrm{~g}$ of material and the visible state of the samples was essentially unchanged after the 14 day test for all eight samples. The leachate solutions and the subsequent acid strip solutions were analyzed via ICP-MS. Table I contains the results from the analysis of the leachates and acid strips which are combined into a single value for each sample.

After 14 days only a small amount of material was present in the test solution. However, the means of analysis (ICP-MS) is extremely sensitive and the values stated in the Table I are sufficiently 
above the limits of quantification as to be reliable within $+/-20 \%$ or better in every case. Any values that are marked with a "- " were below the limit of quantification.

Table I. The Results of the Immersion Tests on Core Samples from Ingots 6 and 7. All release rates are in units of $\left(\mathrm{g} / \mathrm{m}^{2}\right.$ day). The samples are identified by ingot-core number. All values were background corrected.

\begin{tabular}{|l|l|l|l|l|l|l|l|l|l|l|}
\hline Id. & $\mathrm{Fe}$ & $\mathrm{Cr}$ & $\mathrm{Ni}$ & $\mathrm{Mo}$ & $\mathrm{Mn}$ & $\mathrm{Tc}$ & $\mathrm{Ru}$ & $\mathrm{Pd}$ & $\mathrm{Zr}$ & $\mathrm{U}$ \\
\hline $6-1$ & $4.5 \mathrm{E}-3$ & $4.8 \mathrm{E}-4$ & $4.3 \mathrm{E}-3$ & $5.5 \mathrm{E}-3$ & $1.34 \mathrm{E}-1$ & $2.8 \mathrm{E}-3$ & $2.0 \mathrm{E}-3$ & $1.13 \mathrm{E}-2$ & $2.1 \mathrm{E}-3$ & $8.1 \mathrm{E}-2$ \\
\hline $6-2^{*}$ & - & $3.6 \mathrm{E}-4$ & $1.2 \mathrm{E}-3$ & $5.88 \mathrm{E}-2$ & $8.0 \mathrm{E}-3$ & $2.2 \mathrm{E}-3$ & $1.4 \mathrm{E}-3$ & $3 \mathrm{E}-5$ & $6 \mathrm{E}-4$ & $2.76 \mathrm{E}-2$ \\
\hline $6-3^{*}$ & - & $2.2 \mathrm{E}-4$ & $1.1 \mathrm{E}-3$ & $5.74 \mathrm{E}-2$ & $1.54 \mathrm{E}-2$ & $1.4 \mathrm{E}-3$ & $2.2 \mathrm{E}-3$ & $5.88 \mathrm{E}-3$ & $1.4 \mathrm{E}-3$ & $3.84 \mathrm{E}-2$ \\
\hline $6-4$ & - & - & $4.3 \mathrm{E}-3$ & $6.4 \mathrm{E}-3$ & $5.18 \mathrm{E}-2$ & $3.1 \mathrm{E}-3$ & $1.9 \mathrm{E}-3$ & $3.22 \mathrm{E}-3$ & $7 \mathrm{E}-4$ & $2.40 \mathrm{E}-2$ \\
\hline $7-1$ & - & - & $1.68 \mathrm{E}-2$ & $3 \mathrm{E}-4$ & $5.32 \mathrm{E}-2$ & $3.0 \mathrm{E}-3$ & $1.4 \mathrm{E}-3$ & $2.03 \mathrm{E}-2$ & $8 \mathrm{E}-4$ & $1.43 \mathrm{E}-1$ \\
\hline $7-2$ & - & - & $4.5 \mathrm{E}-3$ & $1.82 \mathrm{E}-2$ & $7.42 \mathrm{E}-2$ & $5 \mathrm{E}-4$ & - & $4.2 \mathrm{E}-3$ & $1.19 \mathrm{E}-2$ & $2.98 \mathrm{E}-2$ \\
\hline $7-3^{*}$ & $2.2 \mathrm{E}-3$ & $2.2 \mathrm{E}-3$ & $9 \mathrm{E}-4$ & $5.88 \mathrm{E}-2$ & $9.9 \mathrm{E}-3$ & $2 \mathrm{E}-4$ & $1.3 \mathrm{E}-3$ & $3.08 \mathrm{E}-3$ & $1.4 \mathrm{E}-3$ & $1.28 \mathrm{E}-1$ \\
\hline $7-4^{*}$ & - & - & $4 \mathrm{E}-4$ & $6.16 \mathrm{E}-2$ & $1.11 \mathrm{E}-2$ & $9 \mathrm{E}-4$ & $1.3 \mathrm{E}-3$ & - & $2.8 \mathrm{E}-3$ & $3.78 \mathrm{E}-2$ \\
\hline
\end{tabular}

*These leachants are $\$ J-13$ water.

There are several observations and comments that can be made upon reviewing the results presented above. Some of these observations are based on the separate results of the acid strip and test solutions that are presented combined fashion in Table I. These observations are: 1) the NML for stainless steel constituents stated in Table I does not include contributions from the acid strip solution since the blanks indicated that some degree of attack of the acid on the vessel itself occurred, 2) the NML of Tc and $\mathrm{Ru}$ is sometimes higher in the acid strip and sometimes higher in the leachate, 3) the NML of Pd is always higher in the acid strip and rarely present in the leachate, 4) the NML of $\mathrm{Zr}$ is always approximately an order of magnitude higher in the acid strip solution versus the leachate solution, 5) there is no statistical difference between samples from the same ingot subjected to ASTM Type I water versus SJ-13 water, 6) the NML for $U$ is always higher in the acid strip solution versus the leachate which is consistent with the solubility of uranium in water and 7) there appears to be roughly equal NML for $U$ from ingot 6 and 7 considering the scatter in the results.

\section{Long-Term Pulsed Flow Test}

The purpose of the immersion testing is two-fold: to assess the release behavior of the technetium and uranium and to determine whether this release behavior changed with variations in the alloy composition. The changes in composition investigated were: 1) the amount of uranium present, 2 or $11 \mathrm{wt} \%, 2$ ) the amount of technetium present, 0.3 or $1.0 \mathrm{wt} \%$ and 3 ) the total amount of noble metals present, 0.7 or $4.0 \mathrm{wt} \%$. The amount of the major constituent stainless steel was essentially kept constant at 73-78wt\%. The testing results featured here vary in duration from 200 to 500 days.

Two sets of samples were cast with compositions of $316 \mathrm{SS} / 15 \mathrm{Zr} / 4 \mathrm{NM} / 2 \mathrm{U} / 1 \mathrm{Tc}$ (sample \#34) and $316 \mathrm{SS} / 15 \mathrm{Zr} / 0.6 \mathrm{Ru} / 0.3 \mathrm{Pd} / 11 \mathrm{U} / 0.3 \mathrm{Tc}$ (sample \#63). The latter of these two sample compositions was chosen after several castings were performed of the demonstration-scale metal waste forms with irradiated cladding hulls and an elemental analysis completed. The ruthenium, palladium and technetium concentrations were chosen to simulate those found in the metal waste ingots while the uranium level was chosen to provide a bounding value. The uranium and technetium release was monitored over time. A representative plot of this behavior is presented in Fig. 1. The estimated forward reaction rate for uranium appears to be roughly an order of magnitude higher than that for technetium, $5 \mathrm{E}-3$ versus $6 \mathrm{E}-4$ ( $\mathrm{g} / \mathrm{m}^{2}$ day). This is unusual in terms of the expected solubility of uranium and technetium in water with oxidized form of technetium being much more soluble. The presence of other ions in the SJ-13 was not anticipated to change the relative solubility of the two analytes in question. This behavior warrants further investigation in light of the premise that uranium is our representative actinide. The caveat being that the heptavalent form of technetium is very soluble but the quadravalent form is very insoluble. The speciatation of the technetium could be determined through one of two means: through direct examination of the surface corrosion products or through a chemical analysis of the solution after a vigorous cleaning of the vessel walls and especially the sample itself with an appropriate solvent. The acid must solubilize the corrosion products without appreciable attacking the alloy itself or changing the valence state of the technetium. The chemical method would give a better quantitative answer than a method such as Auger spectroscopy which could examine the surface. The drawback to the direct chemical examination is the concentration of the Tc in solutions is on the order of 5E-7 M or less which makes spectroscopic methods challenging since the absorptivity constant is only $5930 \mathrm{Lmol}^{-1} \mathrm{~cm}^{-1}[11]$. An 
analysis of the corrosion products of a sample with $2 \mathrm{wt} \% \mathrm{Tc}$ subjected to leach test for 450 days at $90^{\circ} \mathrm{C}$ yielded no detectable Tc-containing corrosion products.

Even with the unusual behavior noted, the behavior of uranium is reasonable when compared to an actinide-doped simulated high-level waste glass [12-14]. The long-term release rates observed by Fortner and Bates [13] for uranium in doped glasses meant to simulate products produced at the Defense Waste Processing Facility and West Valley Demonstration Project were 1.4E-3 and 3.9E-4 $\left(\mathrm{g} / \mathrm{m}^{2} \mathrm{day}\right)$, respectively. These compare favorably with that presented here for several simulated metal waste form samples.

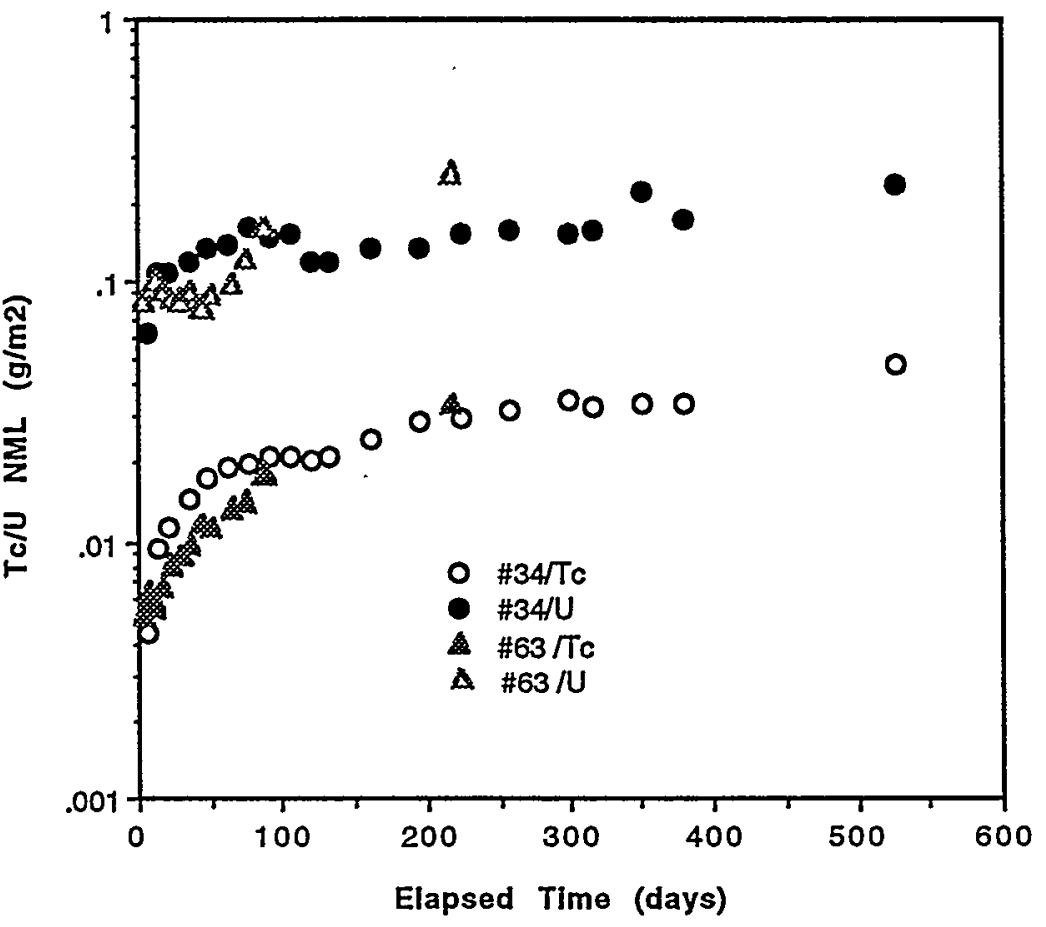

Figure 1. The Results from the Pulsed Flow Test. Please see the text for sample composition.

\section{Crushed Sample Test}

The investigation of using an immersion test to measure the product consistency of the metal waste form was driven by the need to have a means of assessing product consistency of the as-cast waste form. Preliminary tests using a different, and unsatisfactory, sample preparation method (liquid nitrogen treatment followed by an impact mortar) to obtain crushed samples were undertaken and initiated the sample preparation methods discussed here [10].

Table II. Normalized Mass Loss for the Crushed Sample Immersion Test. The SAVV was $2000 \mathrm{~m}^{-1}$ for the test. All values have been blank corrected and are in units of $\left(\mathrm{g} / \mathrm{m}^{2}\right)$. DBMM and BSMM stand for drill bit/micromill and band saw/micromill, respectively. $\mathrm{T}=90^{\circ} \mathrm{C}$ and the test duration was 14 days.

\begin{tabular}{|l|l|l|l|l|l|l|}
\hline Sample Id. & $\mathrm{Fe}$ & $\mathrm{Cr}$ & $\mathrm{Ni}$ & $\mathrm{Mo}$ & $\mathrm{Mn}$ & $\mathrm{Zr}$ \\
\hline DBMM-1-W & $<4.3 \mathrm{E}-5$ & $<8.6 \mathrm{E}-6$ & $5.0 \mathrm{E}-5$ & $2.6 \mathrm{E}-2$ & $2.0 \mathrm{E}-4$ & $1.8 \mathrm{E}-5$ \\
& & & & & & \\
\hline DBMM-2-W & $<4.3 \mathrm{E}-5$ & $<8.6 \mathrm{E}-6$ & $3.5 \mathrm{E}-5$ & $2.6 \mathrm{E}-2$ & $1.9 \mathrm{E}-4$ & $1.7 \mathrm{E}-5$ \\
\hline BSMM-1-W & $<4.2 \mathrm{E}-5$ & $5.4 \mathrm{E}-5$ & $3.4 \mathrm{E}-5$ & $1.3 \mathrm{E}-2$ & $1.3 \mathrm{E}-4$ & $2.2 \mathrm{E}-6$ \\
\hline BSMM-2-W & $<4.2 \mathrm{E}-5$ & $1.7 \mathrm{E}-5$ & $3.6 \mathrm{E}-5$ & $1.7 \mathrm{E}-2$ & $1.5 \mathrm{E}-4$ & $1.5 \mathrm{E}-6$ \\
\hline
\end{tabular}

The material from all three sample preparation methods was tested as described above. The results for the second two methods are presented in Table II. The primary focus of the investigation 
was to examine the release of the major constituents present in every anticipated metal waste product to be produced. Thus the following analytes were chosen: $\mathrm{Fe}, \mathrm{Cr}, \mathrm{Ni}, \mathrm{Mo}, \mathrm{Mn}$, and $\mathrm{Zr}$. This approach is mimicking that applied to high level waste glass where the matrix elements of Si and $\mathrm{B}$ are the primary analytes. (Others could be added in the future if desired).

To investigate the material actually used for the test after preparation SEM was employed. This would evaluate whether the microstructure was damaged during sample preparation and whether the sample utilized was representative of the whole. Figure 2 is a low magnification back scattered electron (BSE) SEM micrograph showing general characteristics of the material. The actual material displayed in Fig. 2 is post-test material from the 14 day PCT carried out in the DI water. Figure 2 represents a long axis view of a representative particle. This cross section indicates that the fundamental microstructure is unchanged during preparation and that the particle is a representative sample of the bulk. The SEM analysis shows that some distortion of the microstructure does occur near some of the edges in the form of enhanced porosity. However, the physical dimensions of the phases is such that they are very small compared to the particle size fraction used for the test and so the minor distortion observed should not be a dominant factor.

Observations

1) The release of material to solution is low but detectable in most cases. The repeatability. of the test will have to be evaluated further to establish release limits for the various elements.

2) The material is somewhat distorted by the sample preparation but should be useable for this type of test.

3) The sample preparation means are reasonable from a hot cell applicability viewpoint.

4) Further tests will need to be performed on alloys of differing compositions to assess their behavior.

5) This test may be applicable as a product consistency test although no repository relevant data would be obtained with it.

6) A suitable metal standard should be chosen and established to run concurrently with the PCT to insure test-to-test repeatability.

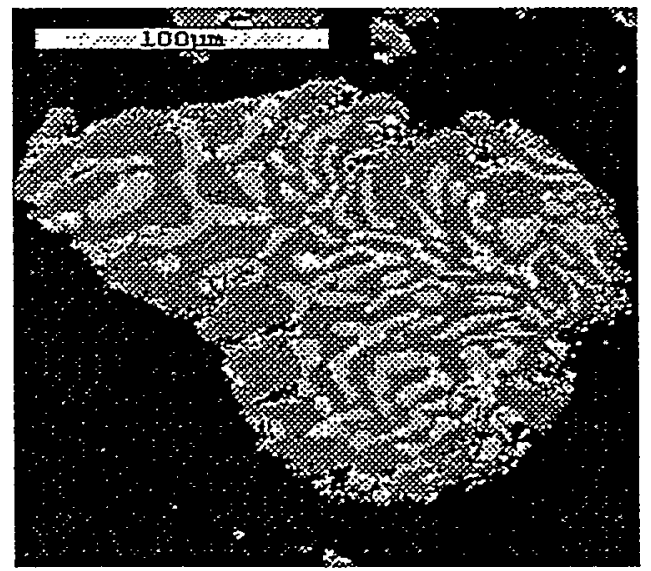

Figure 2. A Cross Section of a Representative PCT Particle Produced Using the Bandsaw/Micromill Preparation Method after Undergoing 14 Day Test. Please refer to [1] for a description of the phases.

\section{CONCLUSIONS}

The results presented here for the monolithic immersion test indicate that under the conditions used, 14 days at $90^{\circ} \mathrm{C}$, the metal waste form exhibits NRR that vary from $1 \mathrm{E}-3$ to $1 \mathrm{E}-5 \mathrm{~g} / \mathrm{m}^{2}$ for the major constituents of stainless steel and zirconium. These being the essential "matrix" elements of the metal waste form. The release of the noble metal fission products, $\mathrm{Tc}, \mathrm{Ru}$, and Pd, exhibit NRRs of $1 \mathrm{E}-3$ to $1 \mathrm{E}-5 \mathrm{~g} / \mathrm{m}^{2}$.

Interim long-term pulsed flow immersion test results were presented for technetium and uranium spiked simulated metal waste forms. The release rates obtained were less than or equal to $5 \mathrm{E}-3$ ( $\mathrm{g} / \mathrm{m}^{2} \mathrm{day}$ ) for both technetium and uranium. Variations in the noble metal, uranium and technetium contents had negligible effect on the release rates for technetium and uranium from those alloys. 
The results for the crushed sample immersion test indicate that samples representative of the whole can be prepared and the release of the major elements $(\mathrm{Cr}, \mathrm{Ni}, \mathrm{Mo}, \mathrm{Mn}, \mathrm{Zr})$ during a 14 day test can be determined. The NML for $\mathrm{Mn}, \mathrm{Zr}, \mathrm{Fe}, \mathrm{Zr}$ and $\mathrm{Ni}$ are all $2 \mathrm{E}-4 \mathrm{~g} / \mathrm{m}^{2}$ or less for this test. The NML for Mo is approximately $2 \mathrm{E}-2 \mathrm{~g} / \mathrm{m}^{2}$. The reason for the much higher release of Mo is still under investigation. Additional results must be obtained before the use of this test can be considered for the purpose of process control of production of the metal waste form.

No report on immersion testing of a metal-based high-level waste form would be considered complete without some mention of electrochemical corrosion. The species being released to the leachate are oxidized into solution and thus electrochemical corrosion has been investigated for the metal waste form using either cold alloy [1] or technetium or uranium doped alloys [13]. These tests have yielded results that should be comparable to those obtained here for the monolithic tests performed. The reported corrosion rates obtained are 0.5-2 micrometers per year for neutral $\mathrm{pH}$ values. If one compares these rates to those obtained for the initial four weeks of the pulsed flow measurements (these would estimate the forward reaction rate) it is found that the electrochemical value over-estimates that observed corrosion rate by a factor of 12-50. The production of a layer of corrosion products may passivate the waste form from further corrosion. Microscopy has been applied to a sample of the technetium-doped metal waste form after being immersed for 450 days. Very little in the way of corrosion products were observed on the surface. Another possible explanation of the discrepancy would be the deposition of corrosion products onto the internal surface of the leach vessel. The concentration of the uranium and technetium in solution is less than $2 \mathrm{ppm}$ for the uranium and less than $1 \mathrm{ppm}$ for the technetium so a solubility-driven argument would be inconsistent with this. This behavior is still under investigation at this time.

The choice of an immersion test to apply to the metal waste form produced from the electrometallurgical treatment process at Argonne for the purpose of process control is not straightforward. The electrochemical methods $[1,14]$ are useful but sample preparation is very demanding and impractical for irradiated samples. The pulsed flow test described here is lengthy and requires extensive sample handling. The monolithic test is less demanding experimentally but the scatter in the results obtained from samples taken from a single ingot make its application as a process control test questionable for the metal waste form. The crushed sample test is workable in a remote environment and the samples are representative of the matrix as a whole. Yet, additional data is required before a decision can be reached. The use of alternative leachants, instead of water, and the interpretation of results may require additional effort. 'Other methods of analyzing the metal waste form are still being considered such as density, hardness or microscopy. These methods suffer either from lack of sensitivity, extensive sample preparation or insufficient quantitation.

\section{REFERENCES}

[1] McDeavitt, S. M., Abraham, D. P., Park, J. Y., J. Nucl. Mat., 257, 21 (1998).

[2] Keiser, D. D., Westphal, B. W., ANS Proceedings "Third Topical Meeting DOE Spent Nuclear Fuel and Fissile Materials Management", Charleston, SC, 668 (1998).

[3] Office of Civilian Radioactive Waste Management, Waste Acceptance System Requirements Document, E00000000-00811-1708-00001, rev. 2 (1996).

[4] Marra, J. C., Marra, S. L., Bibler, N. E., ANS Proceedings "Third Topical Meeting DOE Spent Nuclear Fuel and Fissile Materials Management", Charleston, SC, 731 (1998).

[5] Johnson, S. G., Keiser, D. D., Noy, M., O'Holleran, T. P., Frank, S. M., MRS proceeding Sci. Basis Waste Mang. 1998, in press (1999).

[6] Barkatt, Aa., Macedo, P. B., Gibson, B. C., Mowad, R., Sousanpour, W., Barkatt, Al., Boroomand, M. A., Adel-Hadadi, M. Rogers, V. L., Waste Management '85, Vol. 1, 471 (1985).

[7] Barkatt, Aa., Macedo, P. B., Sousanpour, W., Barkatt, Al., Boroomand, M. A., Fisher, C. F., Shirron, J. J., Szoke, P., Rogers, V. L., Nucl. and Chem. Waste Management, 4, 153 (1983).

[8] Mendel, J. E., ed., Final Report of the Defense High-Level Waste Leaching Mechanisms Program, PNL-5157 (1984).

[9] C1220-97, "Determining Chemical Durability of Nuclear, Hazardous, and Mixed Waste Glasses: The Product Consistency Test (PCT)", ASTM, Philadelphia (1999).

[10] Abraham, D., Argonne National Laboratory, Private communication (1998).

[11] Vida, J., PNL-TR-497, Battelle Pacific Northwest National Laboratory (1994).

[12] Bradley, D. J., Harvey, C. O., Turcotte, R. P., "Leaching of Actinides and Technetium from Simulated HighLevel Waste Glass", PNL-3152 (1979).

[13] Fortner, J. A., Bates, J. K., Mat. Res. Soc., 412, 205 (1997).

[14] Abraham, D. P., Keiser, D. D., Peterson, Katyal, N. K., Proc. Fall 1999 mtg. Nat. Assoc. Corrosion Eng., in press (1999). 